\title{
COMPARISON OF EGG WEIGHT AND EGG SHELL STRENGTH IN TWO GENOTYPES OF LAYING HENS
}

\author{
Nedeljka Nikolova ${ }^{1}$, Dragoslav Kocevski ${ }^{2}$, Gjoko Bunevski ${ }^{2}$, Vladimir Džabirski ${ }^{2}$, Vlado Vuković ${ }^{2}$, \\ Kočo Porču ${ }^{2}$, Marjan Tanevski ${ }^{3}$, Goran Tasev ${ }^{3}$, Daniel Simonoski $^{2}$ \\ 1 "Ss. Cyril and Methodius" University in Skopje, Institute of Animal Science, \\ Blvd. Ilinden 92a, 1000 Skopje, Republic of Macedonia \\ 2"Ss. Cyril and Methodius" University in Skopje, Faculty for Agricultural Science and Food, \\ Institute for Animal Biotechnology, \\ Blvd. Aleksandar Makedonski bb, 1000 Skopje, Republic of Macedonia \\ ${ }^{3}$ NGO SREBRA, Association of Breeders of Domestic Village Chickens, \\ Ivan Naumov Alabakot Str. 63a, 1000 Skopje, Republic of Macedonia \\ nikolova13@gmail.com
}

\begin{abstract}
Comparative study of two, for the marketing most important, egg quality parameters (egg weight and egg shell strength) in two genotypes of commercial laying hens was realized. Egg production, egg weight (size) and egg shell strength in ISA Brown $(14,879)$ and DeKalb White $(15,376)$ layers, housed in battery cages under similar in-house environment and feed complete mixtures according the technological nutrient recommendation, were followed through the laying cycle. Egg weight and egg shell strength were analyzed in the Laboratory for testing egg quality using Egg shell Gauge (Robotmation Co. Ltd., Tokyo, Japan), computerized equipment that perform unbiased, shell breaking strength values. Both genotypes have high egg production that was close to the technological level of laying. No differences in egg number/hen housed were noticed. DeKalb White layers produce on average $1 \mathrm{~g}$ bigger eggs than the ISA Brown line layers (64.18 g vs $63.17 \mathrm{~g})$, resulting in better feed to egg mass conversion. ISA Brown layers produce eggs with stronger egg shell $\left(3864.52 \mathrm{~g} / \mathrm{cm}^{2}\right)$ compared to DeKalb White genotype $\left(3575.78 \mathrm{~g} / \mathrm{cm}^{2}\right)$. High summer temperature influence the strength of the egg shell in both genotypes, resulting in lower strength compared to average egg shell strength values.
\end{abstract}

Key words: egg weight; egg shell strength; genotype; layers

\section{СПОРЕДБА НА МАСАТА И ЦВРСТИНАТА НА ЛУШПАТА НА ЈАЈЦАТА ОД ДВА ГЕМОТИПА НЕСИЛКИ}

\begin{abstract}
Извршено е споредбено истражување на две, за пазарот најважни, особини на квалитетот на јајцата (маса на јајцата и цврстина на лушпата) кај два генотипа комерцијални несилки. Во текот на циклусот на несење беа следените параметри: производство на јајца, маса на јајцата и цврстина на јајцевата лушпа кај хибридните несилки од ISA кафеави (14.879) и DeKalb бели (15.376), сместени во батериски кафезен систем под слични амбиентални услови и исхрана која соодветствува со технолошки препорачаната. Масата на јајцата и цврстината на лушпата беа испитувани во лабораторијата за квалитет на јајца со помош на компјутеризиран инструмент наречен Egg shell Gauge (Robotmation Co. Ltd., Tokyo, Japan), кој ја одредува вредноста на силата на кршење на лушпата. Обата генотипа имаа високо производство на јајца што беше многу близу до технолошкото. Не беа забележени разлики во бројот на јајца по вселена кокошка. Белите DeKalb несилки произвеле во просек за $1 \mathrm{~g}$ потешки јајца отколку несилките на ISA кафеави (64,18 g наспроти $63,17 \mathrm{~g}$ ), што е резултат на подобра искористеност на храната за производство на јајцевата маса (конверзија). ISA кафеавите несилки произведоа јајца со поцврста јајцева лушпа $\left(3864,52 \mathrm{~g} / \mathrm{cm}^{2}\right)$ во однос на оние од DeKalb бели несилки $\left(3575,78 \mathrm{~g} / \mathrm{cm}^{2}\right)$. Високите летни температури влијаат на цврстината на јајцевата лушпа кај двата генотипа, резултирајќи со послаба цврстина на јајцата во однос на просечната вредност.
\end{abstract}




\section{INTRODUCTION}

Egg shell quality (strength) could be the main factor contributing to the profitability of layer farm producing table eggs for shell egg market (shell egg market presents $99 \%$ of the marketing approach in R. Macedonia). If shell strength is defined as marketing quality parameter, than this characteristics is important for producers but also for consumers. Beside egg shell quality, maybe the most important marketing parameter is egg weight or egg size. There are different methods for measuring egg shell quality or strength like, percentage of egg shell, thickness of egg shell, specific weight of the eggs submersed in different salt solutions but direct strength of egg shell measured through automatic equipment for egg shell breakage, gives the most reliable, precise and unbiased results. There are different factors contributing to egg shell quality but if modern technologies of housing, feeding and management are applied then the most important factor contributing to it is genotype or strain or line of hens (Buss and Guyer 1982).

Pandey et al. (1986) found variation in egg weight and egg shell thickness between different genotypes of layers. Significant variations in egg weight were noticed by many researchers (Monira et al., 2003; Anderson et al., 2004).

Nikolova and Kocevski (2004), Nikolova et al. (2008) and later Kocevski et al. (2011) reported differences in egg weight and quality (strenght) of egg shell due to genotypes and also as influenced by season (high summer temperature).

\section{MATERIAL AND METHODS}

The analyses were made regarding production results (laying), i.e. the intensity of laying in two flocks of laying hens placed in battery cages in separate farmhouses of the same farm location. The laying hens were at the same age and exploated during the same period in which they were fed with balanced feeding mixture meeting the requirements for the individual genotype. One of the flock was composed of 15.376 laying hens of Dekalb White (white laying hens which give eggs with white egg shell) genetic provenience, and the other flock were 14.879 laying hens of ISA Brown (brown hens which give eggs with brown egg shell) genetic provenience.

Analyses of the strength of the egg shell were made in the laboratory for control of the marketing quality of eggs in the Institute for Animal Biotechnology at the Faculty of Agricultural Sciences and Food on an automated machine for measuring the egg strength (Eggshell Force Gauge).

\section{RESULTS AND DISCUSSION}

Hybrid laying hens of Dekalb White genetic provenience and ISA Brown genetic provenience are known for good production which was confirmed in our conditions, i.e. in the analyzed flocks which are subject of this work. As it can be seen from the Figs. 1 and 2, they have almost the same egg production, i.e. they have approximately the same intensity of egg production in the examined period. It can be seen at the Figs. 1 and 2 that they do not deviate much from the technologically determined intensity of laying of both hybrids, which means that they are suitable for keeping in conditions of Republic of Macedonia.

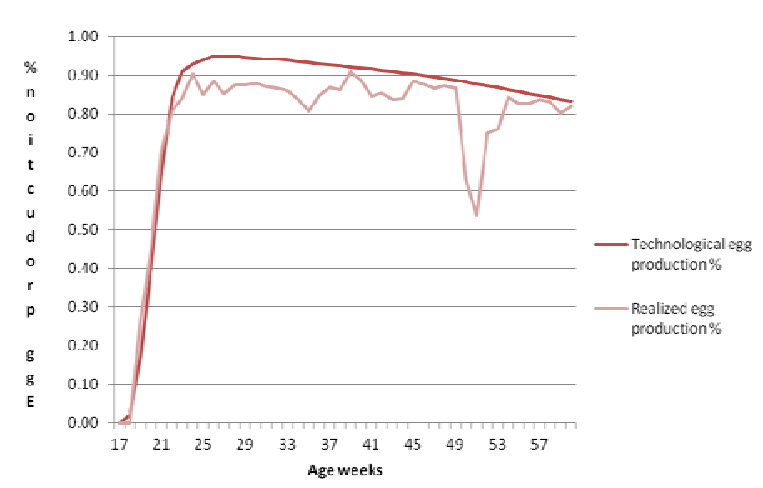

Fig. 1, Egg production \% ISA Brown genotyp

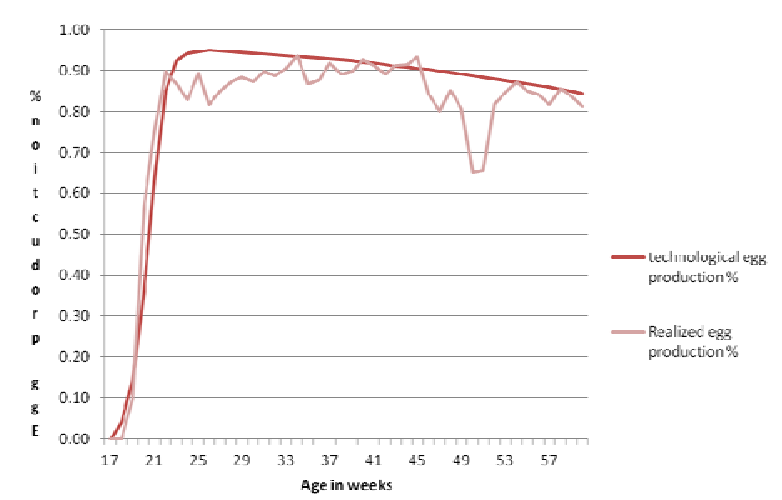

Fig. 2,. Egg production \% Dekalb White genotype

The analyses of egg mass and egg shell strength, as the most important factors which determine the number of eggs suitable for sale (Table 
1) actually were the main subjects of the analysis in this paper. They shown that:

- Eggs obtained from the hybrid Dekalb White (genetic provenience lay) were one gram heavier than eggs laid by ISA Brown genetic provenience.

- Eggs obtained from the hybrid ISA Brown (genetic provenience lay) had significantly stronger egg shell than eggs laid by Dekalb White genetic provenience.

- Egg laying hybrids of Dekalb White genetic provenience and the laying hens of ISA Brown genetic provenience equally react to the stress caused by high temperatures in the course of summer months (June, July, August and September) when they lay eggs with significantly decreased strength of the shell.

Table 1

Egg shell strength $\left(\mathrm{g} / \mathrm{cm}^{2}\right)$ and size (mass, $\mathrm{g}$ ) of the eggs in the two analyzed hybrid types of laying hens

\begin{tabular}{lcccccc}
\hline & Genotype & \multicolumn{2}{c}{ ISA Brown } & \multicolumn{2}{c}{ Dekalb White } & \multicolumn{3}{c}{ Average value for both genotypes } \\
& Egg shell strength & Egg mass & Egg shell strength & Egg mass & Egg shell strength & Egg mass \\
\hline March & 3955.25 & 61.32 & 3723.89 & 60.61 & 3839.57 & 60.97 \\
April & 4122.33 & 61.55 & 3799.27 & 63.95 & 3960.80 & 62.75 \\
May & 3977.42 & 61.87 & 3833.73 & 63.33 & 3905.58 & 62.60 \\
June & 3751.32 & 63.89 & 3345.67 & 64.89 & 3548.50 & 64.39 \\
July & 3633.22 & 64.35 & 3401.28 & 64.78 & 3517.25 & 64.57 \\
August & 3576.88 & 64.19 & 3379.23 & 64.56 & 3478.06 & 64.38 \\
September & 3777.39 & 64.29 & 3399.04 & 64.86 & 3588.22 & 64.58 \\
October & 3888.57 & 63.99 & 3611.23 & 64.98 & 3749.90 & 64.49 \\
November & 4098.27 & 63.12 & 3688.67 & 65.66 & 3893.47 & 64.39 \\
\hline Average value & 3864.52 & 63.17 & 3575.78 & 64.18 & 3720.15 & 63.68 \\
Standard deviation & 193.42 & 1.26 & 195.48 & 1.49 & 188.46 & 1.28 \\
Maximum & 4122.33 & 64.35 & 3833.73 & 65.66 & 3960.80 & 64.58 \\
Minimum & 3576.88 & 61.32 & 3345.67 & 60.61 & 3478.06 & 60.97 \\
\hline \hline
\end{tabular}

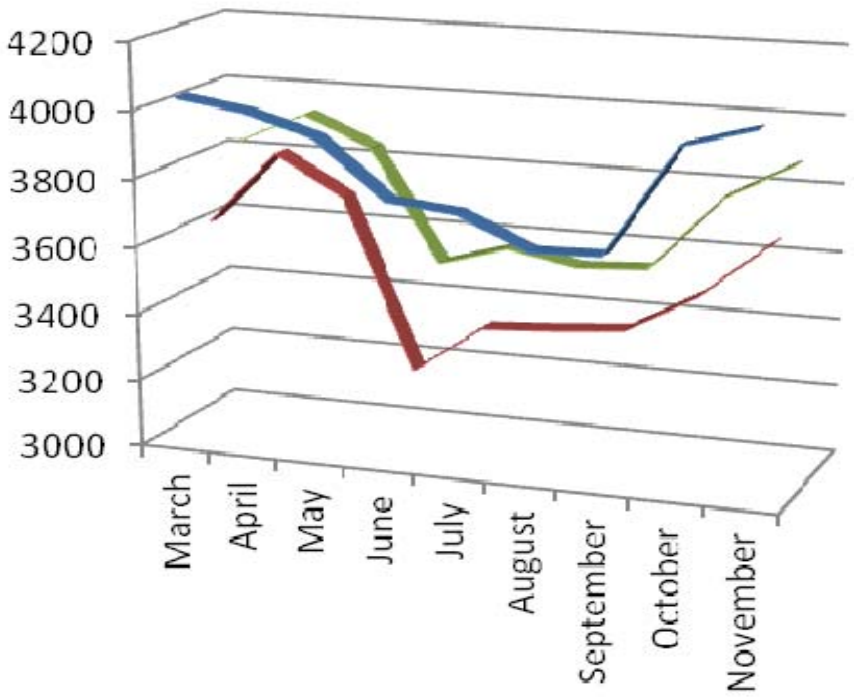

Eggshell strength ISA Brown

Eggshell strength Dekalb White

Average value for eggshell strength forboth genotypes

Fig. 3. Egg shell strength in commercial genotypes $\left(\mathrm{g} / \mathrm{cm}^{2}\right)$ 
Genotype had significant $(\mathrm{P}<0.05)$ effects on the performance traits studied with the exception of egg cracks (Yakubu et al., 2007). Variable egg production performance for various strains of chicken had been reported (Tolmir and Masic, 2000). Kocevski et al. (2011) found significant differences $(\mathrm{P}<0.05)$ in eggs shell strength examined under genotype and age influence and the values of the same declined for both lines of hens (ISA Brown and DeKalb), though less for ISA Brown. These results are in compliance with results of Zita et al. (2009) where the shell of ISA Brown eggs had significantly $(\mathrm{P}<0.001)$ greater quality then others genotypes during the all period of research.

Season significantly $(\mathrm{P}<0.05)$ affected egg production, feed intake, egg weight, egg crack and mortality (Yakubu et al., 2007). Egg production, egg weight and feed intake were higher in the wet season compared with the hot-dry season. Incidence of egg cracks and mortality was significantly higher in summer season. The same results had been shown in experiment by Nikolova et al. (2008).

\section{CONCLUSIONS} clusion:

The data analyzed lead to the following con-

1. The hybrid laying hens of Dekalb White genetic provenience lay for an average of one gram larger eggs than the laying hens of ISA Brown genetic provenience, which means that they use the feed more efficiently (conversion of the feed into egg mass) because they are smaller in their live mass, the daily consumed feed is less, they lay down almost equal number of eggs (both hybrids show almost identical laying intensity, Figs. 1 and 2), but Dekalb White hybrid would lay down eggs with larger egg mass.

2. The hybrid laying hens of ISA Brown genetic provenience lay down eggs with stronger egg shell than the laying hens of Dekalb White genetic provenience (Fig. 3), which actually means that they provide eggs which are more easily manipulated in the process of production; they also lay down larger number of eggs for sale (less cracked and broken eggs), thus compensating the advantage of the Dekalb White laying hens related to their efficiency (feed conversion ratio) stated in item 1.

3. During the summer, the laying hens of both hybrid types ISA Brown and Dekalb White genetic provenience laying eggs with less strong egg shell, as a result of the high temperatures.

\section{REFERENCES}

[1] Anderson, K. E., Tharrington, J. B., Curtis, P. A., Jones, T.: Shell characteristics of eggs from historic strains of single comb white leghorn chickens and the relationship of egg shape to shell strength. J. Poult. Sci., 3, 1, 17-18 (2004).

[2] Basmacioglu H., Ergul M.: Research on the factors affecting cholesterol content and some other egg characteristics of eggs in laying hens. The effect of genotype and rearing system. Turk. Vet. Anim. Sci. 29: 157-164 (2005)..

[3] Buss, E. G., Guyer, R. B.: Genetic differences in avian egg shell formation. Poult. Sci., 61, 2048-2055 (1982).

[4] Kocevski D., Nikolova N., Kuzelov A.: The influence of strain and age on some egg quality parameters of commercial laying hens. Biotechnology in Animal Husbandry, 27, 4, 1649-1659 (2011) Belgrade-Zemun, R. Serbia.

[5] Monira, K. N., Salahuddin, M., Miah, G.: Effect of breed and holding period on egg quality characteristics of chicken. Inter. J. Poult. Sci., 2, 4, 261-263 (2003).

[6] Nikolova, N., Kocevski, D.: Influence of season on physical and chemical characteristics of hen's egg shell. Biotechnology in Animal Husbandry, 20, 5-6, 165-174 (2004) Belgrade-Zemun, R. Serbia.

[7] Nikolova N., Pavlovski Z., Milošević N., Weahner M.: Influence of heat stress and age on the percentage of calcium carbonate in egg shell and the percentage of broken and cracked eggs, submitted 12. 2007. In: Archives of Animal Breeding, 51, 4, 389-396 (2008), Germany, Dummerstorf.

[8] Pandey, N. K., Mahapatra, C. M., Verma, S. S., Johari, D. C.: Effect of strain on physical egg quality characteristics in White Leghorn chickens. Ind. J. Poult. Sci., 21, 304307 (1986).

[9] Tolmir N., Masić B.: The results of European egg production tests in 1978-1998. Živinarstvo, 35: 66-68 (2000).

[10] Yakubu A., Salako A. E., Ige A. O.: Effects of genotype and housing system on the laying performance of chickens in different seasons in the semi-humid tropics. Inter. Jour. of Poult. Sci. 6: 434-439 (2007).

[11] Zita L., Tumova E., Stolc L.: Effects of genotype, age and their interaction on egg quality in brown-egg laying hens. Acta Vet. Brno 78, 85-91 (2009) 